\title{
Analysis and Simulation of SEIRS model for Hepatitis B
}

\author{
Syafruddin Side ${ }^{1}$, Muhammad $\mathrm{Abdy}^{2}$, and Wahidah Sanusi ${ }^{3}$ \\ \{syafruddin@unm.ac.id'1 , abdy02@yahoo.com ${ }_{2}^{2}$ wahidah.sanusi@unm.ac.id ${ }^{3}$ \} \\ Department of Mathematics, Faculty of Mathematics and Natural Sciences,Universitas Negeri \\ Makassar, Daeng Tata St, Parang Tambung, Tamalate, Kota Makassar, Sulawesi Selatan 90224. Telp \\ (62411)864936 $1,2,3$
}

\begin{abstract}
This study discusses the process of the SEIRS model on the spread for Hepatitis B. The mathematical model of the SEIRS for Hapatitis B is a model by dividing the population class into four variables namely Susceptible-Exposed-Infected-RecoveredSuspected (SEIRS) which is a four-dimensional nonlinear differential equation system. The model obtained analysed and simulated using data assuming the initial values of variables and parameters and processed using Maple Software. The results of this study provide a SEIRS model of the spread of Hepatitis B. Simulation results also provide predictions of the number of cases for Hepatitis B sufferers who can be a preventative solution., both free disease and endemic cases for Hepatitis B. If the basic reproduction number, $R_{0}>1$, the hepatitis B disease becomes endemic and if the basic reproduction number $R_{0} \leq 1$, the hepatitis B disease will disappear by itself or free disease.
\end{abstract}

Keywords: Hepatitis B, SEIRS Model, Endemic and free disease

\section{Introduction}

Hepatitis B is a contagious disease that has a high spread rate. Symptoms of Hepatitis B Specifically the signs and symptoms of acute hepatitis B are fever, abdominal pain, and jaundice. But for people with chronic hepatitis B tend not to appear these signs, so transmission to others becomes more risky. Handling and Treatment of Hepatitis B. Patients suspected of Hepatitis B, for the certainty of the diagnosis that is upheld, a blood check is performed. After the diagnosis is established as Hepatitis B, then there is a way of treatment for hepatitis B, which is swallowed (oral) and injection treatment [1].

Around the world today, it is estimated that around two billion people are infected with the Hepatitis B virus. 240 million people are chronically infected and 780,000 people die each year from being infected with Hepatitis B virus, 650,000 from cirrhosis and liver cancer due to chronic Hepatitis B virus infection and 130,000 from Hepatitis B acute [2].

Indonesia is ranked 3rd in the world number of Hepatitis B sufferers, with a population of around 13 million. In Indonesia, the prevalence of hepatitis B sufferers shows a large variation, from moderate to high. South Sulawesi Province was ranked 3rd in the number of patients with Hepatitis B in Indonesia in 2013 as in Figure 1 [2]. Based on data from the Directorate General of Disease Control and Environmental Health of the Ministry of Health in 2009, from the total 
population of Indonesia, 6-7 million people spread across 21 provinces were infected with the hepatitis $\mathrm{C}$ virus, the majority of which were men of productive age [3] as can be seen on Figure 1.

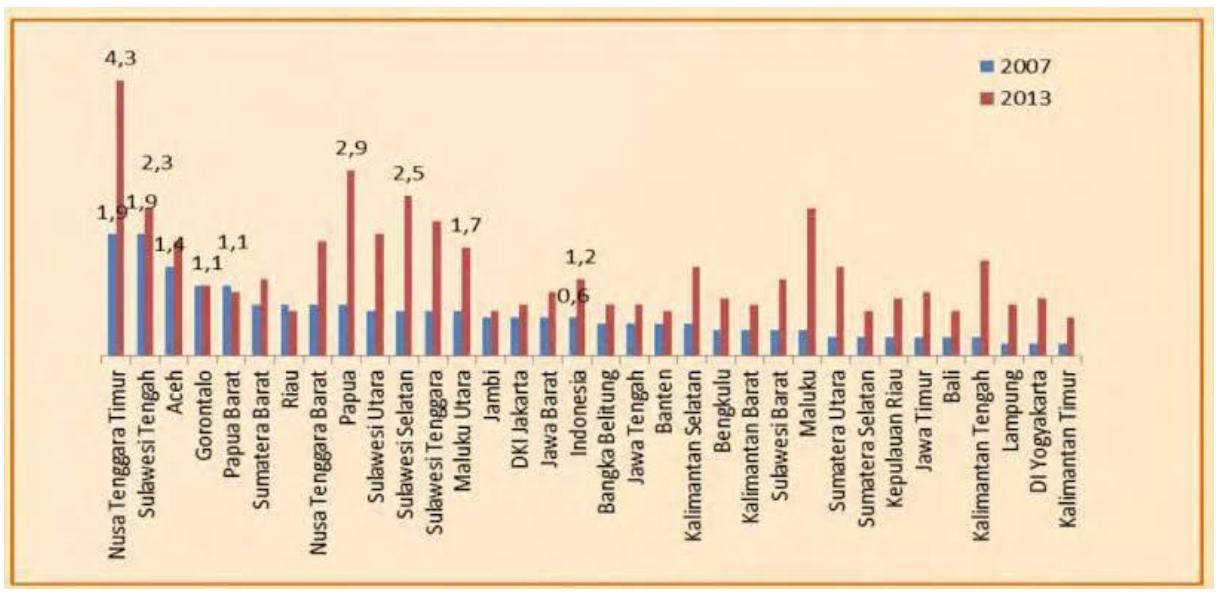

Fig. 1. Hepatitis Prevalence by Province in 2007 and 2013. Source: Indonesian Ministry of Health, 2014

The Indonesian Heart Research Association cooperates with the sub-division of Gastroenterol-Hepatology in Internal Medicine of the Faculty of Medicine, Hasanuddin University, to hold a free hepatitis vaccine injection for the people of Makassar City. In Makassar itself, he said, according to data from Regional Hospital Wahidin Sudirohusodo Makassar, during 2007-2009, of 146 hospitalized patients with the chronic liver disease found positive for hepatitis C 10 people and 59 others infected with hepatitis B [3]. Hepatitis B in Makassar City poses a serious threat to more than eight million residents in 2015, coupled with a lack of public awareness about the importance of health, so it needs attention from the government, especially the ministry of health [3].

Mathematical models are one of the tools that can be used to predict the number of hepatitis B sufferers. Some researchers have made SIR and SEIR mathematical models about infectious diseases such as dengue fever and TB [4-11]. While modeling of hepatitis [2,12-14]. Several studies on the spread of Hepatitis B are SIR type [2,12], which examines the spread of SIR type disease by vaccination with regard to vaccination levels. Both studies have several factors that might influence the spread of disease not considered in the model, one of which is the migration factor. Then [14] discuss the SEIR mathematical modeling of hepatitis B transmission in Makassar City, but the novelty of this paper is: this study assumes that healthy populations become immune from Hepatitis B, these models also have not produced the most appropriate predictions, because that this research will build the SEIRS model as a modification of the SEIR model by assuming that a healthy population can become a suspect again from hepatitis $\mathrm{B}$. The population become a suspect again because nowadays, global warming and lifestyle for the individual. 


\section{Method}

The first part of this research is to build the SEIRS model in hepatitis B transmission. Furthermore, the analysis of the model is to determine the existence and stability of the SEIRS model, then simulate using assumption data on the number of Hepatitis B cases using MatLab programming to predict the number of Hepatiits B cases.

\section{Results and Discussion}

\subsection{Model SEIRS for Hepatitis B Transmission}

The changes that occur in each human population in the transmission of hepatitis B for the SEIRS model can be interpreted in the following Schema Figure 2.

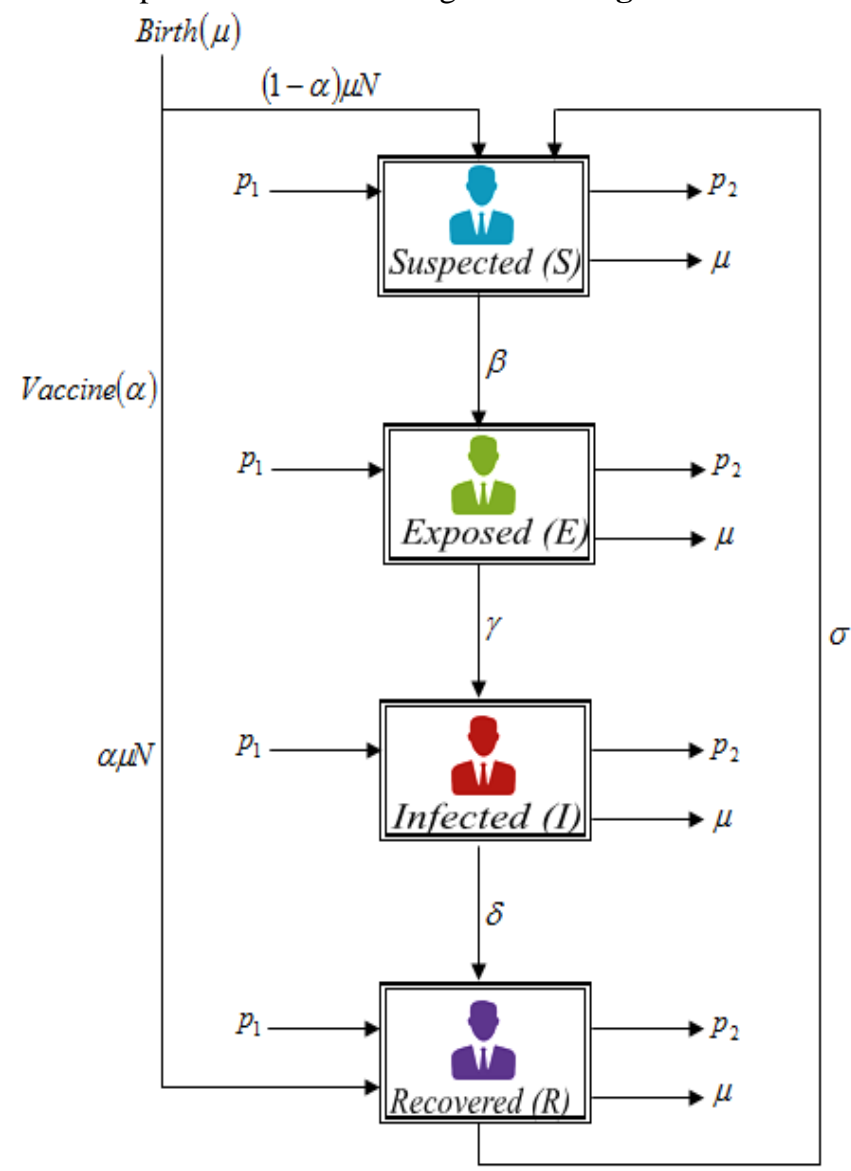

Fig. 2. Schema of the SEIRS Model for Transmission of Hepatitis B. 
The definition of variable and parameter explain in Table 1.

Table 1. Initial and parameter values of SEIRS model for Hepatitis B.

\begin{tabular}{cl}
\hline $\begin{array}{c}\text { Variable/ } \\
\text { Parameter }\end{array}$ & \multicolumn{1}{c}{ Definition } \\
\hline $\mathrm{S}$ & The number of suspected population \\
$\mathrm{E}$ & The number of the exposed population \\
$\mathrm{I}$ & The number of the infected population \\
$\mathrm{R}$ & The number of a recovered population \\
$\mathrm{A}$ & Vaccine population \\
$\mathrm{M}$ & Birth or death population \\
$\mathrm{P}_{1}$ & Immigration population \\
$\mathrm{P}_{2}$ & Emigration population \\
$\mathrm{B}$ & The factor rate of suspected to exposed \\
$\Sigma$ & The factor rate of recovered to suspected \\
$\Delta$ & The factor rate of infected to recovered \\
$\Gamma$ & The factor rate of exposure to infected \\
$\mathrm{N}$ & Total population \\
\hline
\end{tabular}

Fig. 1. reformulated into 3-D non-linear differential equations as in the system (1)

$$
\begin{aligned}
& \frac{d S}{d t}=(1-\alpha) \mu N S+p_{1} S+\sigma R-\beta \frac{S I}{N}-\left(p_{2}+\mu\right) S \\
& \frac{d E}{d t}=\beta \frac{S I}{N}+p_{1} E-\left(\gamma+p_{2}+\mu\right) E \\
& \frac{d I}{d t}=\gamma E+p_{1} I-\left(\delta+p_{2}+\mu\right) I \\
& \frac{d R}{d t}=\alpha \mu N S+\delta I+p_{1} R-\left(\sigma+p_{2}+\mu\right) R
\end{aligned}
$$

with

$$
N(t)=S(t)+E(t)+I(t)+R(t)
$$




$$
R(t)=N(t)-(S(t)+E(t)+I(t))
$$

Then

$$
\begin{aligned}
& N^{\prime}(t)=\frac{d N}{d t}=S^{\prime}(t)+E^{\prime}(t)+I^{\prime}(t)+R^{\prime}(t) \\
& \frac{d x}{d t}=(1-\alpha) \mu N+p_{1} x+\sigma z-\beta x y-\left(p_{2}+\mu\right) x \\
& \frac{d u}{d t}=\beta x y+p_{1} u-\left(\gamma+p_{2}+\mu\right) u \\
& \frac{d y}{d t}=\mu u+p_{1} y-\left(\delta+p_{2}+\mu\right) y \\
& \frac{d z}{d t}=\alpha \mu N+\delta y+p_{1} z-\left(\sigma+p_{2}+\mu\right) z
\end{aligned}
$$

The system (4) is a SEIRS model for the spread of Hepatitis B.

\subsection{SEIRS model simulation for free disease and the endemic case of Hepatitis B}

Model simulations are performed using MAPLE software. The initial values of $S(0), E(0)$, $\mathrm{I}(0)$ and $\mathrm{R}(0)$ as well as the parameter values of the model based on the assumptions presented used in this simulation are shown in Table 2 and by [15], the basic reproduction number $R_{0}$ obtained in Equation 5 follow:

$$
R_{0}=\frac{\left(B-p_{1}\right)\left(C-p_{1}\right)\left(D-p_{1}\right)}{\gamma \beta A}
$$

Table 2. Initial and parameter values of SEIRS model for Hepatitis B.

\begin{tabular}{cllllll}
\hline parameter & $\begin{array}{l}\mathrm{R}_{0}>1 \\
\text { value }\end{array}$ & value & $\begin{array}{l}\mathrm{R}_{0} \leq 1 \\
\text { value }\end{array}$ & value & Variable & Initial value \\
& 0.95 & 0.9 & 0.55 & 0.50 & $\mathrm{~N}(0)$ & 11506 \\
$\mu$ & 0.45 & 0.4 & 0.1 & 0.2 & $\mathrm{~S}(0)$ & 3361 \\
$\alpha$ & 0.1 & 0.15 & 0.4 & 0.45 & $\mathrm{E}(0)$ & 3361 \\
$p_{1}$ & 0.15 & 0.17 & 0.02 & 0.01 & $\mathrm{I}(0)$ & 3361 \\
$p_{2}$ & 0.75 & 0.65 & 0.5 & 0.6 & $\mathrm{R}(0)$ & 1432 \\
$\beta$ & & & & &
\end{tabular}




$\begin{array}{lllll}\gamma & 0.35 & 0.45 & 0.5 & 0.45 \\ \delta & 0.30 & 0.35 & 0.40 & 0.35 \\ \sigma & 0.2 & 0.2 & 0.2 & 0.15\end{array}$

Based on Table 2, we obtained graphs of free disease cases for Hepatitis B in Figure 3 and Figure 4 follows.

Figure 3 show that the number of suspected individuals each month continues to increase drastically, in contrast to the population of exposed and infected individuals which decline initially but then increase dramatically, whereas for recovered individuals each month is increasing.

Figure 4 show that the number of suspected individuals each month continues to increase drastically, in contrast to the population of exposed and infected individuals which decline initially but then increase dramatically, whereas for recovered individuals each month is increasing.

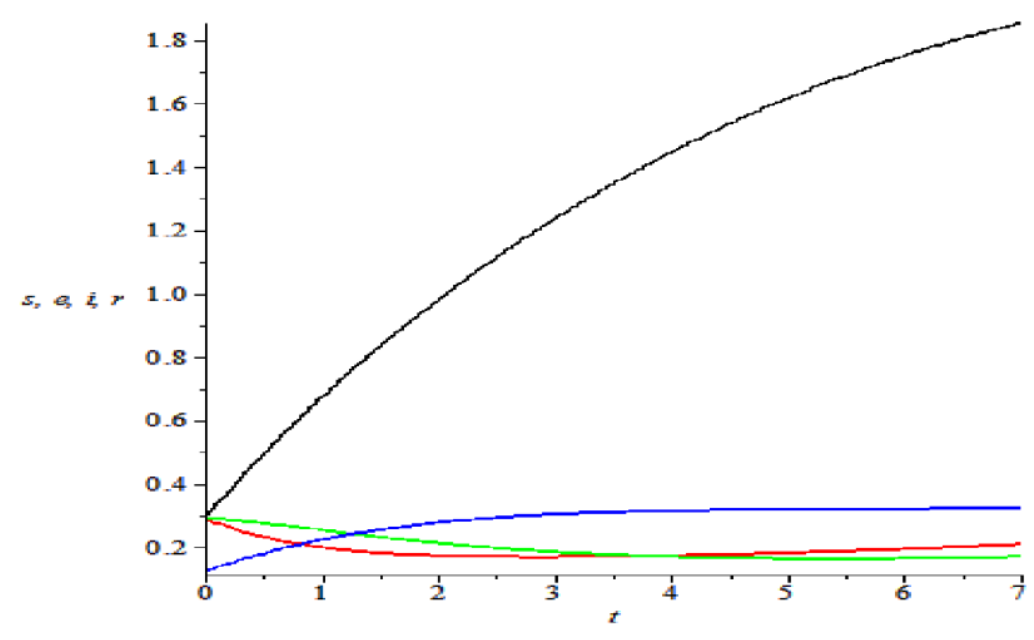


Fig. 3. Proportion of suspected, exposed, infected and recovered population for free disease.

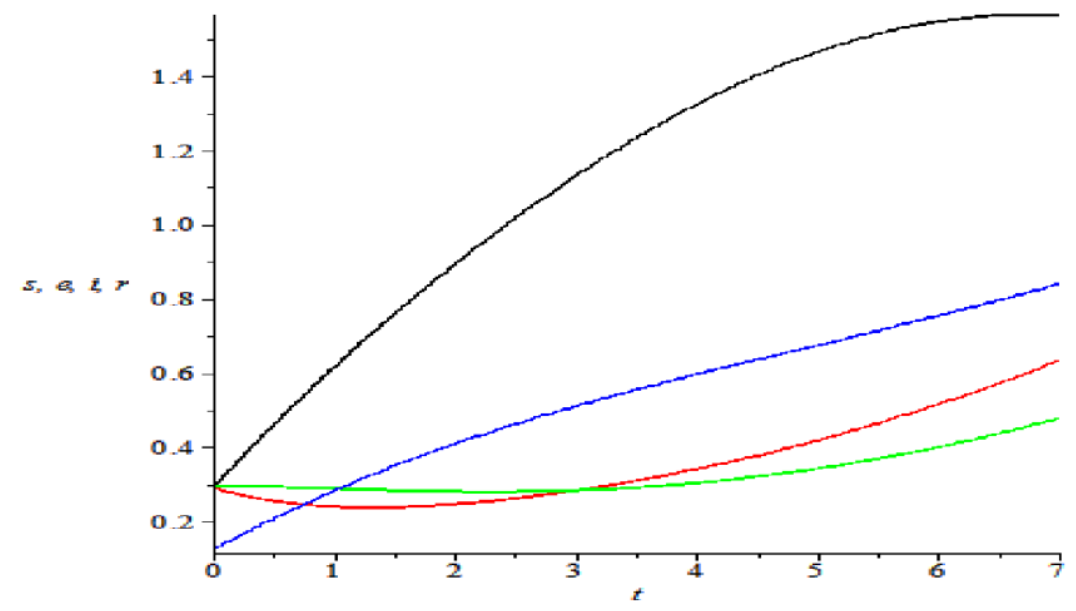

Fig. 4. The proportion of suspected, exposed, infected and recovered population for free disease.

\subsection{SEIRS Model Simulation of Hepatitis B for Endemic Cases}

According to Table 2, we obtained graphs of each parameter value in Figure 5 and Figure 6 follows.

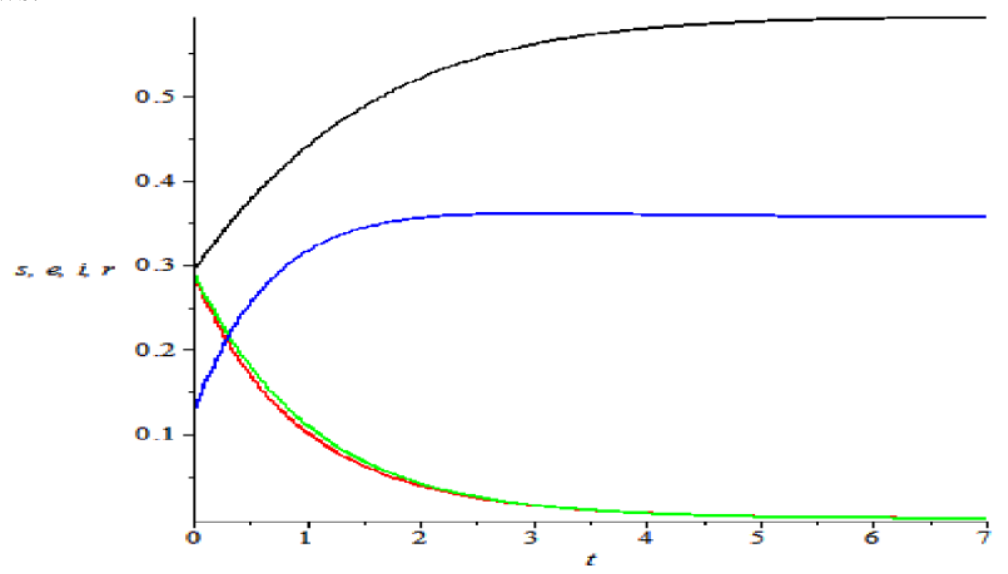

Fig. 5. The proportion of suspected, exposed, infected and recovered population for endemic case.

Figure 5 show that the number of suspected individuals every month continues to increase dramatically, in contrast to the population of exposed and infected individuals which continues to decline, whereas for individuals recovered each month increases at first but then decreases very slowly 


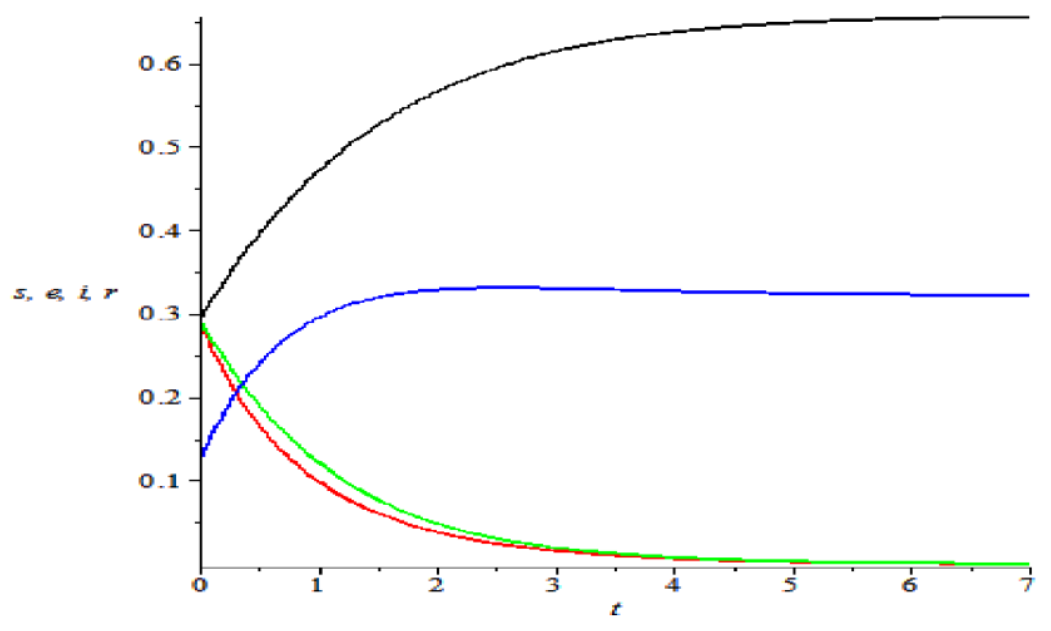

Fig. 6. The proportion of suspected, exposed, infected and recovered population for endemic case.

Figure 6 show that the number of suspected individuals every month continues to increase dramatically, in contrast to the population of exposed and infected individuals which continues to decline, whereas for individuals recovered each month increases at first but then decreases very slowly

\section{Conclusion}

Analysis of the SEIRS mathematical model for the spread of Hepatitis B produced two equilibrium points, namely the disease-free equilibrium point and the asymptotic stable endemic equilibrium point. In addition, the Simulation Results of the SEIRS model using MAPLE for the spread of hepatitis B in both disease-free and endemic cases provide predictive information on the number of cases of Hepatitis B if the condition is free of disease and also the endemic condition of Hepatitis B.

Acknowledgments. We would like thanks to UNM and DIKTI No:124/UN36.9/PL/2019 for financial support.

\section{References}

[1]Surachmat Syahruddin.: Penyakit Hepatitis. http://awalbrosmakassar. blogspot.co.id/2011/10/penyakit-hepatitis.html. (2015) (Access, 7th, February 2019).

[2] Rosdiana.: Pemodelan Matematika SIR dengan Vaksin pada Penyebaran Penyakit Hepatitis B. Skripsi, Universitas Negeri Makassar (2015).

[3]Antara.: Masyarakat Makassar dapat Vaksin Hepatitis Gratis. http://makassar.antaranews.com/berita/17398/masyarakat-makassar-dapat-vaksin-hepatitis-gratis. (2010) (Access, 7th February 2019).

[4] Guihua L \& Zhen J.: Global stability of an SEIR epidemic model with infectious force in latent, infected and immune period. Chaos, Solitons \& Fractals 25:1177-84 (2005) 
[5] Ashley T, Jacqueline S \& John S.: Modeling the spread of Tuberculosis in a Closed Population. http://educ.jmu.edu/ strawbem/math_201/final_reports/Scotti_Takahashi_Spreadbury_Final.pdf.(201 0) [access, 20th, April 2018].

[6] K. Queena, Tjokorda B.O \& I Made E.D.: Model SIR untuk penyebaran penyakit Tuberkulosis. Ejurnal Matematika. Vol 1, No 1: 52-58 (2012)

[7] Idianto, Bayu \& Nilamsari K.: Analisis kestabilan local model dinamika penularan tuberculosis satu strain dengan terapi dan efektivitas Chemoprophylaxis. Buletin Ilmiah Mat. Stat. dan Terapannya. Vol 02. No. 3, 173-182 (2013)

[8] Dontwi I. K, W. Obeng D, E.A Andam \& L. Obiri A.: A mathematical model to predict the prevalence and transmission dynamics of tuberculosis in amansie west district, Ghana. British Journal of Mathematics \& Computer Science. Vol 4(3): $402-4025$ (2014)

[9] Syafruddin S. et. al.: Lyapunov functions of SIR and SEIR model for transmission of dengue fever disease. International Journal Simulation and Process Modeling; Inderscience Publishers 8(2,3):177$184(2013)$

[10] Syafruddin S.: A Susceptible-Infected-Recovered Model and Simulation for Transmission of Tuberculosis. Advanced Science Letters. 21 (2):137-139 (2015)

[11] Rangkuti, Y, M, Syafruddin S, and Nooarni, M. S.: Numerical Analytic Solution of SIR Model of Dengue Fever Disease in South Sulawesi using Homotopy Perturbation Method and Variational Iteration Method. ITB Journal of Science (Journal of Mathematical and Fundamental Sciences). 46A (1):91-105 (2014)

[12] Mulisi, Subro.: Pengaruh Vaksinasi Terhadap Dinamika Populasi pada Model SIR (SusceptibleInfected-Recovered). Tugas Akhir S1 Departemen Matematika Institut Pertanian Bogor (2011)

[13] Larasati D. \& Tjahjana R.H.: Analisis Model Matematika untuk Penyebaran Virus HBV. Jurnal Jurusan Matematika Universitas Diponegoro Semarang (2012)

[14] Syafruddin, Side. et. al.: SEIR model simulation for hepatitis B. AIP Conference Proceedings 1885, 020198 (2017) 